\title{
Evaluation of Student Learning Outcomes in Problem-Based Learning: Study of Its Implementation and Reflection of Successful Factors
}

\author{
Erpin Evendi $1^{*}$, Ni Nyoman Sri Putu Verawati ${ }^{2}$ \\ ${ }^{1}$ Faculty of Tarbiyah and Teacher Training, Universitas Islam Negeri Mataram, Mataram, Indonesia. \\ 2 Physics Education Program, Faculty of Teacher Training and Education, University of Mataram, Mataram, Indonesia.
}

DOI: $\underline{10.29303 / \text { ippipa.v7iSpeciallssue.1099 }}$

\section{Article Info}

Received: October $18^{\text {th }}, 2021$

Revised: November 20th, 2021

Accepted: November 24th, 2021

\begin{abstract}
Behind the successful of teaching using the problem-based learning (PBL) model, -in our best knowledge- it seems that the factors that make its implementation successful in the classroom have not been mentioned, this is related to the purpose of improving student learning outcomes. For this reason, the study of the implementation of the PBL model needs to be explored further. Specifically, the aim of our current study is to evaluate student learning outcomes in implementing the PBL model and reflecting on the learning process using this model. This study is a Classroom Action Research (CAR), which is an examination of activities or actions that are intentionally conducted in a teaching. In the context of this study, the observation is carried out by evaluating student learning outcomes, while the activity or action that is carried out is Problem-Based Learning (PBL) which is carried out in two learning cycles. The subjects for implementing the PBL model were 21 students in an Islamic school (MTs NW - equivalent to Junior High School) in Central Lombok, Indonesia. Quantitative and qualitative approaches were used to analyze student learning outcomes and the learning process using the PBL model. The results of the study showed that there was an increase in student learning outcomes from the first cycle to the second cycle. Individual and classical completeness has been achieved in accordance with predetermined criteria. Finally, we recommend the use of the PBL model for the purpose of improving student learning outcomes. In the PBL model, the role of motivation, cues, encouraging active student participation, and the use of scaffolding are important aspects in the successful implementation of the PBL model.
\end{abstract}

Keywords: Problem Based Learning; Learning Outcome; Reflection

Citation: Evendi, E. ., \& Verawati, N. N. S. P. (2021). Evaluation of Student Learning Outcomes in Problem-Based Learning: Study of Its Implementation and Reflection of Successful Factors. Jurnal Penelitian Pendidikan IPA, 7(SpecialIssue). 69-76. https://doi.org/10.29303/ippipa.v7iSpecialIssue.1099

\section{Introduction}

In recent decades, Science, Technology, Engineering and Maths (STEM) education has attracted increasing attention, as it is often associated with superior human resource development and economic growth (Montgomery \& Fernández-Cárdenas, 2018). On the one hand, independent thinkers are needed in line with the increasing types of jobs in the future that require reliable workers who have specific abilities and skills in certain fields, and this leads to their skills when learning STEM in a school environment. Mastery and knowledge in mathematics has long been considered the most relevant for the development of students' education and work careers in the future (Onion, 2004), in addition to knowledge of science, technology, and engineering. Mathematics is considered as the "Queen of Knowledge" because almost all fields of science are supported by mathematics. For example, in the context of science, teaching the simplest science material (for

\footnotetext{
*Email: erpin_evendi@uinmataram.ac.id
} 
example, measurement material) is based on mastery of mathematics. However, the achievement of competence has been a challenge in teaching mathematics to date (MacDonald, 2020). In the classical teaching mode, it was found that teaching mathematics was very difficult among students with low cognitive levels (Pendlington, 2005).

Learning mathematics is one of the most important basic knowledge because it has a very close relationship with everyday life which aims to hone thinking from complex problems. However, in reality, students at school are more dominant in not liking mathematics because it is considered a difficult subject and has many formulas and calculations. So that it makes students do not have the interest and motivation to learn mathematics which results in low mathematics learning outcomes of students at school (Salamah, 2020). The skills and abilities of educators in teaching mathematics are in the spotlight (MacDonald, 2020). The use of affective learning strategies needs to be implemented if you are to make progress in teaching mathematics (Pendlington, 2005). At the same time, teachers' knowledge of mathematics pedagogy plays an important role in teaching mathematics material (Hill et al., 2008), so that mathematics learning outcomes can be achieved and produce meaningful teaching (MacDonald, 2020). However, the reality is not always as expected, from our observations at an Islamic school (MTs NW) in Central Lombok, Indonesia. Several problems were identified, among others, student learning outcomes are still low (below the minimum completeness criteria set by the school), learning interactions are less attractive, and still using expository methods which are dominated by teacher teaching activities that students feel are less attractive. This causes negative perceptions of students in learning mathematics, where mathematics is still a difficult subject. This is in accordance with the results of previous studies that learning mathematics is always difficult for students if it is not accompanied by the use of effective learning strategies (Pendlington, 2005). This is the challenge that the need for a student-centered interactive learning model is implemented in the classroom.

Based on the view of constructivist learning theory, teaching is not an activity of transferring knowledge from teacher to student, but rather an activity that allows students to build their own knowledge (Darling-Hammond et al., 2020). Teaching means participating with students in forming knowledge, making meaning, and seeking clarity (Aarto-Pesonen \& Piirainen, 2020). Learning is a process of constructing knowledge that is carried out personally and socially (Kimmerle et al., 2015). According to Piaget (in Jemberie, 2021) the process of acquiring knowledge is carried out by students actively through assimilation or accommodation. Along with that, if we want to improve student learning outcomes, it will not be separated from efforts to improve the quality of learning in schools. This can be done by changing the learning paradigm from teacher centered to student centered, and the approach that was originally more textual has turned into contextual. One interesting innovation that accompanied this paradigm shift was the discovery and application of innovative, interactive, and constructive learning models (Banihashem et al., 2021). Previous studies have intensively conducted interactive and innovative learning models in mathematics learning, one of which is Problem-Based Learning (PBL) (Dahl, 2018).

One of the student-centered interactive learning models is PBL (Savery, 2006). A knowledge product can be created and meaningful through a series of discrete tasks through presentation and problem solving (Hung, 2011). Several previous studies that implemented this model on students in schools showed that PBL can improve students' conceptual understanding and have a positive effect on students' long-term knowledge retention (Li \& Tsai, 2017). Students who receive a performing PBL pedagogy have better mathematical reasoning than students who are taught in traditional ways (Wirkala \& Kuhn, 2011). The advantages of PBL include providing opportunities for students to build meaningful knowledge (Pape et al., 2003). Therefore, PBL must be applied in learning from an early age to equip students with the necessary skills in learning at a higher level of education (Hung, 2011). In addition, collaborative learning in PBL becomes a social skill asset for students, and this is a life skill (Sin, 2015).

In implementing PBL - in our best knowledge the factors that make it successful in the classroom have not been mentioned, this has to do with its effectiveness in improving student learning outcomes. For this reason, the study of the implementation of the PBL model needs to be explored further. Specifically, the purpose of our current study is to evaluate student learning outcomes in implementing the PBL model and reflecting on the learning process using this model to identify the factors that make its implementation successful.

\section{Method}

This study is a Classroom Action Research (CAR), which is an examination of activities or actions that are intentionally conducted in a teaching. In the context of this study, observations were made by evaluating student learning outcomes, while the activities or actions that were conducted were ProblemBased Learning (PBL). The subjects for implementing 
the PBL model were 21 students in a private Islamic School (MTs NW - equivalent to Junior High School) in Central Lombok, Indonesia. Quantitative and qualitative approaches were used to analyze student learning outcomes and the processes involved. CAR is carried out in a learning cycle, with four stages, namely; planning, action, observation, and reflection, as presented in Figure 1.

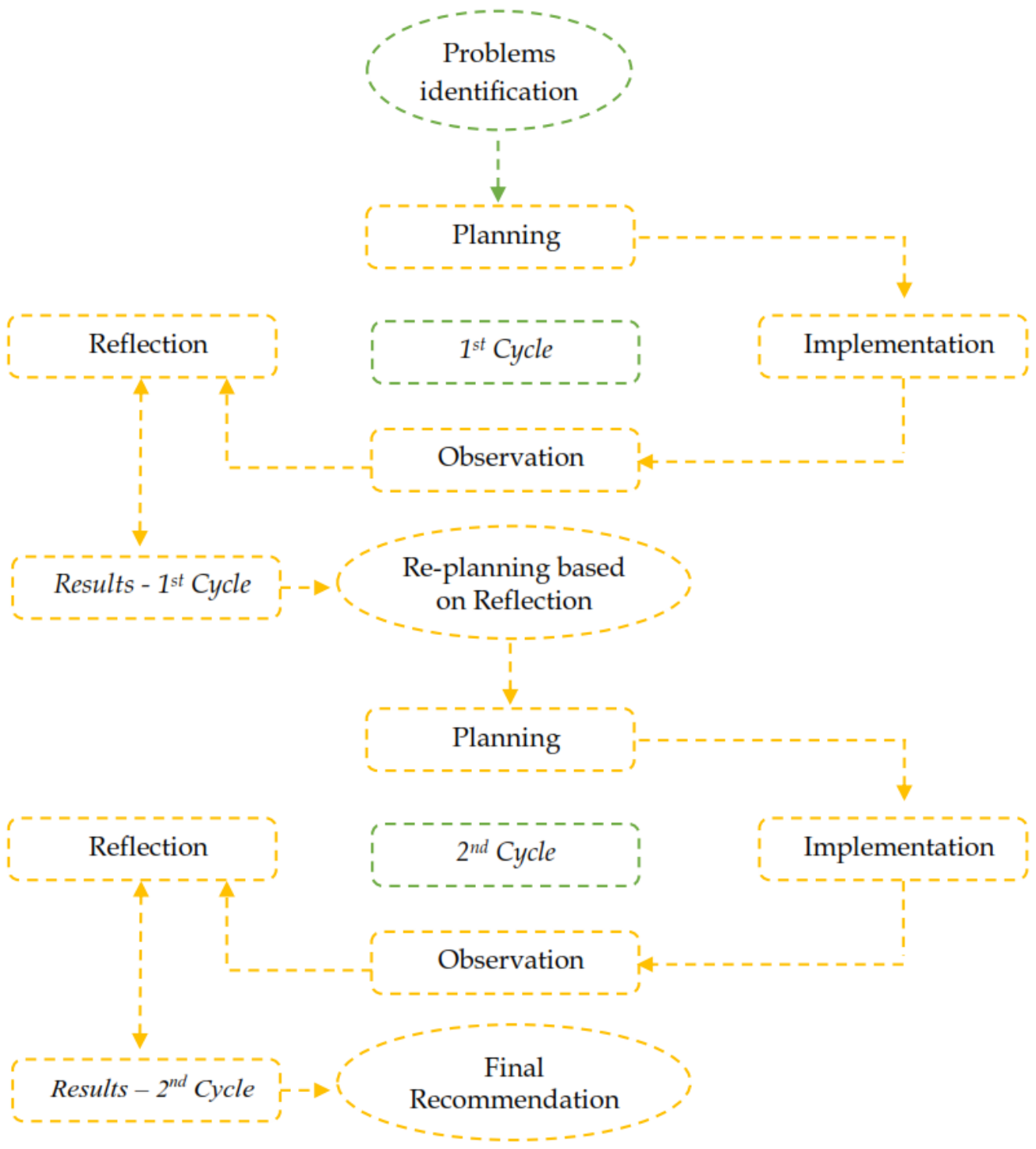

Figure 1. Classroom action research flow

Problem identification has been carried out on school students who are the subject of the study, initial findings include; student learning outcomes are still low (below the minimum completeness criteria set by the school), learning interactions are less attractive, and still using expository methods which are dominated by teacher teaching activities that students feel are less attractive. The solution has been determined based on the analysis of the problem, namely by implementing the PBL learning model. Furthermore, the implementation of actions with this model starts from the planning, implementation, observation, and reflection stages (analysis of student learning outcomes). The implementation of CAR is planned in two learning cycles. The learning tools in the form of syllabus, lesson plans, and instruments used were validated by two validators on the aspects of content and construct validity. The validity criteria (Va) for learning tools are adapted from previous studies (Prayogi et al., 2018), where each aspect of learning tools is stated as; invalid (Va $<1.79)$; less valid $(1.79<$ $\mathrm{Va}<2.60)$; quite valid $(2.60<\mathrm{Va}<3.40)$; valid $(3.40<$ $\mathrm{Va}<4.21)$; and very valid ( $\mathrm{Va}>4.21$ ).

The research instrument to collect data on learning outcomes is a test, using an essay test consisting of eight test items that measure aspects of cognitive learning outcomes at levels $\mathrm{C} 1$ to $\mathrm{C} 4$, namely knowledge, understanding, application, and analysis. 
Furthermore, a quantitative analysis on student learning outcomes was carried out, this was viewed from the aspect of individual and classical completeness. Each student in the learning process is declared complete individually if the student gets a completeness score of 73. This is calculated according to the formulation, Individual Completeness (IC) = (correct answer score / maximum score) x 100 . Classical completeness is achieved if $85 \%$ of the number of students achieve a score of 73 , this is calculated according to the formulation, Classical Completeness $(\mathrm{CC})=$ (number of students who scored $73 /$ number of students) x $100 \%$. Qualitative analysis is carried out by taking a deeper look at the results of the reflection of each learning cycle, this is to identify the factors that influence the successful implementation of the PBL model in the classroom.

\section{Result and Discussion}

The first cycle begins with planning the implementation of learning using PBL. At this stage, researchers prepare learning tools in the form of syllabus, lesson plans, and learning outcomes test instruments. The learning tool was validated by two validators on the content and construct validity aspects. The validation results are presented as in Table 1.

Table 1. The results of the validation of learning tools on aspects of content and construct validity

\begin{tabular}{lllll}
\hline \multirow{2}{*}{ Learning tools } & \multicolumn{3}{l}{$\begin{array}{l}\text { The average validity rating of the two } \\
\text { validators }\end{array}$} \\
\cline { 2 - 5 } $\begin{array}{l}\text { Content } \\
\text { validity }\end{array}$ & Criteria & $\begin{array}{l}\text { Construct } \\
\text { validity }\end{array}$ & Criteria \\
\hline Syllabus & 4.00 & Valid & 3.94 & Valid \\
Lesson plan & 4.12 & Valid & 4.10 & Valid \\
Test instrument 4.00 & Valid & 3.86 & Valid \\
\hline
\end{tabular}

The implementation of the actions in the first cycle of learning uses the PBL model, with five phases of learning, namely orienting students to problems, organizing students to learn, guiding investigations, presenting work results, and evaluating results. Each mode of student learning activities using the PBL model was observed qualitatively. Observation results show that student learning activities are still not optimal, this is because students are not familiar with learning patterns that are oriented towards presenting authentic problems. This has an impact on student learning outcomes who have not met the minimum completeness criteria individually or in groups. The results of the evaluation of student learning outcomes in the first cycle are as presented in Table 2.
Table 2. The evaluation results of the first cycle of learning using the PBL model

\begin{tabular}{lcc}
\hline Variable & $\mathrm{N}$ & Annotation \\
\hline Number of students involved & 21 & - \\
Number of students taking the test & 19 & - \\
Highest score & 74.00 & Range, 0 to 100 \\
Lowest score & 40.00 & Range, 0 to 100 \\
Number of students who completed & 12 & - \\
Average score & 71.58 & Range, 0 to 100 \\
Classical completeness & $63.16 \%$ & Range, 0 to $100 \%$ \\
\hline
\end{tabular}

The results of the evaluation in the first cycle showed that of the 21 students as subjects of the implementation of the PBL model, the number who took the evaluation test was 19 students with an average individual mastery of 71.58. Classical completeness achieved in the first cycle is $63.16 \%$ (less than $85 \%$ ), and this does not meet the minimum criteria for completeness that have been set. Reflecting on the results in Table 1 and the learning process during the implementation of the PBL model, corrective steps were determined to be followed up in the second cycle, namely; a) before presenting the problem, the researcher (as a teacher in the context of this study) needs to motivate students in a more attractive fashion, b) cues (signs) need to be done to direct students to a more specific task context, this is to regulate students' cognitive processes to a context that is more focused on learning materials, c) researchers play a role in building student interaction and collaboration in problem solving, and d) in the investigation process, researchers should actively guide and direct students (in the context of scaffolding), considering that students are not familiar with the investigation process.

Based on the results of the reflection in the first cycle, then the second cycle planning is done by preparing learning tools (which have been declared valid) to be implemented. The implementation of the action using the PBL model refers to the results of the reflection in the first cycle, where the researcher motivates students in the context of authentic problems according to the learning material (as part of the first phase of the PBL model). Furthermore, in the phase of organizing students to learn, researchers used cues to focus students on learning according to the context of the material being studied. Improvements in the implementation phase of the investigation were carried out by encouraging active participation of students in each group, and the investigation was carried out using a scaffolding strategy. Based on these improvement points, the evaluation results of student learning outcomes are presented in Table 3. 
Table 3. The evaluation results of the second cycle of learning using the PBL model

\begin{tabular}{lll}
\hline Variable & $\mathrm{N}$ & Annotation \\
\hline Number of students involved & 21 & - \\
Number of students taking the test & 20 & - \\
Highest score & 86,70 & Range, 0 to 100 \\
Lowest score & 66.70 & Range, 0 to 100 \\
Number of students who completed & 17 & - \\
Average score & 76,67 & Range, 0 to 100 \\
Classical completeness & $85.00 \%$ & Range, 0 to $100 \%$ \\
\hline
\end{tabular}

The results of the evaluation in the second cycle showed that of the 21 students as subjects of the implementation of the PBL model, the number who took the evaluation test was 20 students with an average individual mastery of 76.67. Classical completeness achieved in the first cycle is $85 \%$, this has met the minimum completeness criteria that have been set. Comparison of the results of the evaluation of the first cycle and the second cycle as presented in Figure 2.



Figure 2. Evaluation of the PBL model implementation in the first and second cycles

Reflection on the implementation of learning in the second cycle shows that the implementation of the PBL model has gone well, this is accompanied by several reinforcements in its implementation, namely the important role of motivation, cues, encouraging active student participation, and the use of scaffolding in the investigation process.

The role of motivation in supporting learning success has long been believed to be a very influential factor (Albrecht \& Karabenick, 2018), one of which is the reason for student involvement to take part in learning effectively (Alemayehu \& Chen, 2021). In the learning culture in Indonesia with very diverse students, this motivation is even very influential on student learning outcomes (Prameswari et al., 2020). The findings in this study are in line with previous studies, that the implementation of PBL has a positive impact on the effectiveness of learning by encouraging learning motivation carried out by teachers (Luo, 2019). The success of implementing PBL in the phase of organizing students to learn cannot be separated from using cues to focus students on learning according to the context of the material being studied. The effects of cues to support student success in learning have long been investigated (Landin, 1994), and recent studies have shown that cues are part of a variety of effective learning strategies (Rivera Pérez et al., 2021), in a study our cues are very important combined in PBL.

The active participation of students in learning is an important capital for the successful implementation of PBL in the classroom. In the context of our study, it has been shown that student learning outcomes can increase from the first cycle to the second cycle. The active participation of students creates engagement and motivation to learn which has an impact on learning success (Bergmark \& Westman, 2018). In the context of mathematics learning, it has been investigated where active learning leads to deep understanding of problem solving (Rogers et al., 2021). Finally, what we highlight in implementing PBL is the use of scaffolding in the investigation process. Scaffolding is a form of teacher guidance and encouragement during the learning process, especially to support learning interactions in groups (van de Pol et al., 2019). In the investigation process, scaffolding has been used as a learning model for problem solving (Broman et al., 2018). In another study it was found that scaffolding can change the level 
of strength and self-efficacy in students (Grothérus et al., 2019).

Finally, referring to the final phase of this study within the framework of classroom action research, we provide recommendations on the implementation of the PBL model. First, the PBL model can improve student learning outcomes. Second, the PBL model will be effective in its implementation if the teacher places an important role in motivation in the implementation of PBL, uses cues in learning, encourages active student participation, and uses scaffolding in the investigation process. We believe that the results of this study provide confidence and motivation for teachers to be able to implement the PBL model in particular to improve student learning outcomes.

\section{Conclusion}

Evaluation of student learning outcomes has been carried out on the implementation of the PBL model. Within the framework of classroom action research which was carried out in two cycles, the results of the study showed that there was an increase in student learning outcomes from the first cycle to the second cycle. Individual and classical mastery has been achieved in accordance with predetermined criteria. Finally, we recommend the use of the PBL model for the purpose of improving student learning outcomes. In the PBL model, the role of motivation, cues, encouraging active student participation, and the use of scaffolding are important aspects in the successful implementation of the PBL model.

\section{Acknowledgements}

The author would like to thank those who have contributed to the implementation of this study. A great research team and cooperative partners are important factors in the implementation of this study. Weaknesses and limitations in this study become the spirit for further studies to be carried out in the future.

\section{References}

Aarto-Pesonen, L., \& Piirainen, A. (2020). Teacher students' meaningful learning in widening learning worlds. Teaching Education, 31(3), 323342.

https://doi.org/10.1080/10476210.2018.1561662

Albrecht, J. R., \& Karabenick, S. A. (2018). Relevance for Learning and Motivation in Education. The Journal of Experimental Education, 86(1), 1-10. https://doi.org/10.1080/00220973.2017.1380593

Alemayehu, L., \& Chen, H.-L. (2021). The influence of motivation on learning engagement: The mediating role of learning self-efficacy and selfmonitoring in online learning environments. Interactive Learning Environments, 0(0), 1-14. https://doi.org/10.1080/10494820.2021.1977962

Banihashem, S. K., Farrokhnia, M., Badali, M., \& Noroozi, O. (2021). The impacts of constructivist learning design and learning analytics on students' engagement and self-regulation. Innovations in Education and Teaching International, $0(0), \quad 1-11$. https://doi.org/10.1080/14703297.2021.1890634

Bergmark, U., \& Westman, S. (2018). Student participation within teacher education: Emphasising democratic values, engagement and learning for a future profession. Higher Education Research \& Development, 37(7), 1352-1365. https:// doi.org/10.1080/07294360.2018.1484708

Broman, K., Bernholt, S., \& Parchmann, I. (2018). Using model-based scaffolds to support students solving context-based chemistry problems. International Journal of Science Education, 40(10), 1176-1197.

https://doi.org/10.1080/09500693.2018.1470350

Dahl, B. (2018). What is the problem in problem-based learning in higher education mathematics. European Journal of Engineering Education, 43(1), 112-125. https://doi.org/10.1080/03043797.2017.1320354

Darling-Hammond, L., Flook, L., Cook-Harvey, C., Barron, B., \& Osher, D. (2020). Implications for educational practice of the science of learning and development. Applied Developmental Science, 24(2),

97-140. https://doi.org/10.1080/10888691.2018.1537791

Grothérus, A., Jeppsson, F., \& Samuelsson, J. (2019). Formative Scaffolding: How to alter the level and strength of self-efficacy and foster self-regulation in a mathematics test situation. Educational Action Research, 27(5), 667-690. https://doi.org/10.1080/09650792.2018.1538893

Hill, H. C., Blunk, M. L., Charalambous, C. Y., Lewis, J. M., Phelps, G. C., Sleep, L., \& Ball, D. L. (2008). Mathematical Knowledge for Teaching and the Mathematical Quality of Instruction: An Exploratory Study. Cognition and Instruction, 26(4), 430-511. https://doi.org/10.1080/07370000802177235

Hung, W. (2011). Theory to reality: A few issues in implementing problem-based learning. Educational Technology Research and Development, 59(4), 529-552. https://doi.org/10.1007/s11423011-9198-1

Jemberie, L. W. (2021). Teachers' perception and implementation of constructivist learning approaches: Focus on Ethiopian Institute of 
textile and fashion technology, Bahir Dar. Cogent Education, $8(1)$ 1907955. https://doi.org/10.1080/2331186X.2021.1907955

Kimmerle, J., Moskaliuk, J., Oeberst, A., \& Cress, U. (2015). Learning and Collective Knowledge Construction With Social Media: A ProcessOriented Perspective. Educational Psychologist, 50(2), 120-137. https://doi.org/10.1080/00461520.2015.1036273

Landin, D. (1994). The Role of Verbal Cues in Skill Learning. Quest, 46(3), 299-313. https://doi.org/10.1080/00336297.1994.10484128

Li, H.-C., \& Tsai, T.-L. (2017). The implementation of problem-based learning in a Taiwanese primary mathematics classroom: Lessons learned from the students' side of the story. Educational Studies, 43(3),

354-369. https://doi.org/10.1080/03055698.2016.1277138

Luo, Y.-J. (2019). The influence of problem-based learning on learning effectiveness in students' of varying learning abilities within physical education. Innovations in Education and Teaching International, 56(1), 3-13. https://doi.org/10.1080/14703297.2017.1389288

MacDonald, A. (2020). Mathematics education beliefs and practices of Under 3s educators in Australia. European Early Childhood Education Research Journal, 28(5), 758-769. https://doi.org/10.1080/1350293X.2020.1817246

Montgomery, C., \& Fernández-Cárdenas, J. M. (2018). Teaching STEM education through dialogue and transformative learning: Global significance and local interactions in Mexico and the UK. Journal of Education for Teaching, 44(1), 2-13. https://doi.org/10.1080/02607476.2018.1422606

Onion, A. J. (2004). What use is maths to me? A report on the outcomes from student focus groups. Teaching Mathematics and Its Applications, 23(4), 189-194.

https://doi.org/10.1093/teamat/23.4.189

Pape, S. J., Bell, C. V., \& Yetkin, İE. (2003). Developing Mathematical Thinking and Self-Regulated Learning: A Teaching Experiment in a SeventhGrade Mathematics Classroom. Educational Studies in Mathematics, 53(3), 179-202. https://doi.org/10.1023/A:1026062121857

Pendlington, S. (2005). Mathematics Is Not Easy: The Importance of Teaching Children to Struggle. Research in Mathematics Education, 7(1), 3-17. https://doi.org/10.1080/14794800008520142

Prameswari, N. S., Saud, M., Amboro, J. L., \& Wahyuningsih, N. (2020). The motivation of learning art \& culture among students in Indonesia. Cogent Education, 7(1), 1809770. https://doi.org/10.1080/2331186X.2020.1809770
Prayogi, S., Yuanita, L., \& Wasis. (2018). Critical Inquiry Based Learning: A Model of Learning to Promote Critical Thinking Among Prospective Teachers of Physic. Journal of Turkish Science Education, 15(1), 43-56. https://doi.org/10.12973/tused.10220a

Rivera Pérez, J. F., Hart, R., \& Lund, E. (2021). Vocabulary-learning cues used on children's bilingual programming. Journal of Children and Media, 15(3), 301-319. https://doi.org/10.1080/17482798.2020.1802315

Rogers, K. S., Thomas, C., \& Holmes, H. (2021). Encouraging student participation in mathematical activities in synchronous online tuition. Open Learning: The Journal of Open, Distance and e-Learning, $0(0), \quad 1-17$. https://doi.org/10.1080/02680513.2021.1938523

Salamah, D. P. (2020). Analisis Kesalahan berdasarkan Newman Error Analysis terhadap Materi Peluang Kejadian Majemuk Ditinjau dari Gender dan Self Confidence pada Siswa Kelas XII SMK di Bandung Barat. JPMI (Jurnal Pembelajaran Matematika Inovatif), 3(4), 273-284. https://doi.org/10.22460/jpmi.v3i4.p\%p

Savery, J. R. (2006). Overview of Problem-based Learning: Definitions and Distinctions. Interdisciplinary Journal of Problem-Based Learning, 1(1), Article 1. https://doi.org/10.7771/15415015.1002

Sin, C. (2015). Student-centred learning and disciplinary enculturation: An exploration through physics. Educational Studies, 41(4), 351368.

https://doi.org/10.1080/03055698.2015.1007925

van de Pol, J., Mercer, N., \& Volman, M. (2019). Scaffolding Student Understanding in SmallGroup Work: Students' Uptake of Teacher Support in Subsequent Small-Group Interaction. Journal of the Learning Sciences, 28(2), 206-239. https://doi.org/10.1080/10508406.2018.1522258

Wirkala, C., \& Kuhn, D. (2011). Problem-Based Learning in K-12 Education: Is it Effective and How Does it Achieve its Effects? American Educational Research Journal, 48(5), 1157-1186. http://www.jstor.org/stable/41306381 